\title{
Demographic Factors of Adult-Children on Their Caregiving Values and Options as Home Caregivers to Their Elderly Parents
}

\author{
Yushi Li, Andrea Carter \\ Northern Kentucky University, Highland Heights, KY, USA \\ Email: liyu@nku.edu
}

How to cite this paper: Li, Y.S. and Carter, A. (2017) Demographic Factors of AdultChildren on Their Caregiving Values and Options as Home Caregivers to Their Elderly Parents. Open Journal of Social Sciences, 5, 186-199.

https://doi.org/10.4236/jss.2017.55013

Received: March 7, 2017

Accepted: May 14, 2017

Published: May 17, 2017

Copyright ( 92017 by authors and Scientific Research Publishing Inc. This work is licensed under the Creative Commons Attribution International License (CC BY 4.0).

http://creativecommons.org/licenses/by/4.0/

\begin{abstract}
Traditions in American culture continue to affect the elderly when it comes to choosing their living arrangements. Because there is a strong sense of independence in our society, the elderly population continues to elect to live in their own homes. As their abilities begin to deteriorate, they will need some form of outside care, such as their adult-children's assistance. However, whether the younger generation can take on the caring role or not, their demographics can play a large part in determining their values and options on caring for their elderly parents. In order to comprehend these demographics as well as value factors, a survey was done to study adult-children aged 35 - 55 in the Greater Cincinnati area at the end of 2015. Results of the survey indicated that while adult-children were still willing to take on care responsibilities for their parents, they are also more open to institutionalized services than in the past.
\end{abstract}

\section{Keywords}

Demographic Characteristics, Adult-Children, Elderly Parents, Home Care, Care Values and Options, Living Arrangement Options

\section{Introduction}

As the baby boomers began having children, the American family size was greatly affected (Willetts, 2011) [1]. Due to their childhood life experiences normally in larger families, the baby-boom cohort has chosen to have fewer children. According to Rogerson and Kim (2005) [2], the baby-boom cohort normally had their children between the ages of 25 and 35 . When they reach the age of 55, most of them became empty nesters. Traditionally, the preferred living arrangement for the elderly in American society is to remain in their own homes 
after retirement. This occurs because of their desires to live an independent lifestyle as long as possible. In fact, only about $5 \%$ of the elderly utilize institutionalized care facilities (Hearl, 2011) [3]. According to East (2010) [4], the majority of the elderly choose living at home but they do not want to burden any relatives, especially their children, with caregiving responsibilities. However, as they continue to age, there comes a reduced ability to fulfill everyday care needs. Yet, this decrease in ability does not necessarily mean that they need intensive care, like those care services provided by institutionalized facilities. Such juxtaposition can create a gap in the elderly's life, where they may begin to depend on some form of home care. During this period, their adult-children may need to provide them certain help (Scommegna, 2016) [5].

\section{Literature Review}

As studies (Family Caregiver Alliance, 2015) [6] show that the number of elderly who used paid long-term care services, such as at home or assisted living will double from the 13 million in 2000 to 27 million people in 2050. However, a higher percentage of elderly parents will remain at home. They can either seek some home care services or depend on their adult-children' support (Scommegna, 2016) [5]. The period when adult-children are the primary caregivers vary, most elderly will end up in an institutionalized care service at some point in their lives (Spillman and Lubitz, 2002) [7]. Often, the model of caregiving begins with aging parents acting as independent as possible. Once the elderly are no longer able to be independent, adult-children must take on more responsibilities. This is usually the longest period of the caregiving process (Raina et al., 2004) [8]. Rogerson and Kim (2005) [2] anticipate that it is possible that their care demands will be greater on the baby boomers' children.

The responsibility of home care that their adult-children take on has created a "sandwich generation." The term refers to the stress caused by the amount of care that the adult-children must provide to their own family and children as well as their elderly parents (Neal and Hammer, 2007; Williams, 2004) [9] [10]. According to Stuifbergen and Van Delden (2011) [11], caregiving is a duty to care about one's parents, not for one's parents. Adult-children have their own family, employment status, care values, and preferred living arrangement options for their parents. These important factors can either persuade or deter them to offer such care at home that their elderly parents may need. It also creates conditions for the care and support of family members in times of need (Min and Barrio, 2009) [12].

According to Parker and Patten (2013) [13], 47\% of adult-children in their middle ages have at least a parent aged 65 or older, and at the same time, they are either raising a child of their own and/or financially supporting older children over the age of 18 . Therefore, the adult-children's own family as well as their marital status can be an influential variable when studying caregiving values and options to their parents (Scommegna, 2016) [5]. This is because, in general, a caregiver's demographic background may facilitate or discourage him/her to of- 
fer assistance when their elderly parents need. Sex is also an important demographic variable because females are more likely to be a caregiver (Ramnarace, 2010) [14]. Traditionally, gender is one of the most important factor when studying the amount of assistance an adult-child will provide to their elderly parents and caregiving aligned with a natural female attribution (Bui, 2014) [15].

According to Scommegna (2016) [5], the variables, such as residential distance that an adult-child is from his/her elderly parents and the number of siblings a caregiver has can influence the caregiving to their elderly parents. Furthermore, the elderly parents' health status is also an important factor, which influences what kind of caregiving by their adult-children (Ramnarace, 2010; Pinquart and Sorensen, 2003) [14] [16], such as if they are able to satisfy their parents' caring needs or if they can handle their parents who may have severe health conditions. The point in which the elderly start requiring assistance varies based on their age, health, and abilities. More than likely, younger adult-children caring for older parents experience more sacrifice strain, which results in higher levels of stress, than older adult-children who take care of their relatively younger parents (Pinquart \& Sörensen, 2011) [17]. The adult-children's age (Cherlin, 2010) [18] also affects the caregiving if they are able and/or willing to provide care once their parents are elderly.

Another demographic factor that hinders adult-children is their housing situation (Bonsang, 2007) [19]. If an adult-child rents instead of owning a home, complications may occur like having enough space for their parents. Income levels of the adult-children also play a large role in determining who cares for the elderly (Bonsang, 2007) [19]. On the condition that the elderly cannot afford any nursing home expenses, the adult-children may carry some of that financial burden. Deciding on who pays for the caregiving in terms of time as well as money is one of the most significant factors (Bonsang, 2007) [19]. Dividing caregiving responsibilities among siblings can make the process a much smoother process (Tolkacheva, 2011) [20]. However, as the average family size continues to decrease, this option may not be available for many adult-children. According to the above studies, demographic variables of adult-children can be influential on their care values and options on the caregiving to their elderly parents.

\section{Methodology}

This research studies adult-children's care values and options for their elderly parents. It focuses on the respondents' demographic background variables, as well as how these variables influence their care values and options on the caregiving to their elderly parents. The variables measuring respondents' care values and options are the following eight questions. They are: 1 ) if the respondents feel it is a problem to take care of the elderly parents, 2) if they are able to offer care in their parents' home or in their own home, 3) the best living arrangements for their parents who are 75 years or older, 4) if the elderly should seek out their own professional care, 5) if nursing homes are too expensive for the elderly, 6) if nursing homes are an option for the elderly parents, 7) if elderly parents can 
support nursing home finances, and 8) if the respondents worry about their parents when they become elderly. The demographic variables in the survey include the respondents' levels of education, sex, income, the number of siblings, their residential patterns, such as if they rent or own their homes, their parents' health status, and if they believe that they will be a future caregiver.

In order to comprehensively understand the impact levels of adult-children's demographic variables on their care values and options, a self-answered questionnaire was completed at the end of 2015 in the Greater Cincinnati area by a random sample of 100 respondents aged 35 - 55, who also have at least one living elderly parent. The crosstab statistics are meant to analyze the demographic factors of the respondents as well as how their personal care values and options affect their caregiving to the elderly parents.

\section{Analysis}

Table 1 shows participants aged 35 to 55 (adult-children). Among them, 43\% were between the ages of 35 and 45 . There were $57 \%$ of respondents aged 46 to 55 . The majority of the respondents were married $(80 \%)$ and most of them were working at the time of the survey (88\%). As far as yearly income, $73 \%$ of them earned $\$ 50,000$ or more. The majority of them (52\%) had 1 or 2 siblings and $33 \%$ of them had 3 or 4 siblings. Most of the respondents (84\%) were not providing care at the time of the survey, but $56 \%$ of them expected to be a caregiver in the future. Lastly, over half of the respondents stated that their mother's (54\%) and father's (52\%) health status was good to excellent (see Table 1).

Table 1. Demographic characteristics of adult-children respondents $(n=100)$.

\begin{tabular}{|c|c|c|c|c|}
\hline & $\%$ of participants & $\%$ of participants & $\%$ of participants & $\%$ of participants \\
\hline $\operatorname{Sex}$ & Female (53\%) & Male $(47 \%)$ & & \\
\hline Age range & $35-40(20 \%)$ & $41-45(23 \%)$ & $46-50(27 \%)$ & $51-55(30 \%)$ \\
\hline Marital status & Married (80\%) & Single $(9 \%)$ & Divorced (9\%) & Other $(2 \%)$ \\
\hline $\begin{array}{l}\text { Employment } \\
\text { status }\end{array}$ & Yes $(88 \%)$ & No $(12 \%)$ & & \\
\hline Education & $\begin{array}{l}\text { High school/below } \\
\qquad(21 \%)\end{array}$ & $\begin{array}{c}\text { Some or college } \\
(63 \%)\end{array}$ & $\begin{array}{c}\text { Graduate levels } \\
(16 \%)\end{array}$ & \\
\hline Income & $\begin{array}{c}\$ 24,999 \text { and lower } \\
(7 \%)\end{array}$ & $\begin{array}{c}\$ 25,000-\$ 49,999 \\
(20 \%)\end{array}$ & $\begin{array}{c}\$ 50,000-\$ 74,999 \\
(35 \%)\end{array}$ & $\begin{array}{c}\$ 75,000 \text { and up } \\
(38 \%)\end{array}$ \\
\hline $\begin{array}{l}\text { Number of } \\
\text { siblings }\end{array}$ & No siblings (4\%) & 1 - 2 siblings (52\%) & 3 - 4 siblings (34\%) & $\begin{array}{c}5-13 \text { siblings } \\
(10 \%)\end{array}$ \\
\hline $\begin{array}{l}\text { Current } \\
\text { residential status }\end{array}$ & Renting (15\%) & House owner (85\%) & & \\
\hline $\begin{array}{l}\text { Current } \\
\text { caregiver status }\end{array}$ & Yes $(16 \%)$ & No $(84 \%)$ & & \\
\hline $\begin{array}{c}\text { Future } \\
\text { caregiving status }\end{array}$ & Yes $(56 \%)$ & No $(44 \%)$ & & \\
\hline $\begin{array}{l}\text { My mother's } \\
\text { health status }\end{array}$ & Excellent/good (54\%) & Average (27\%) & $\begin{array}{c}\text { Not good/poor } \\
(19 \%)\end{array}$ & \\
\hline $\begin{array}{l}\text { My father's } \\
\text { health status }\end{array}$ & Excellent/good (52\%) & Average (19\%) & $\begin{array}{c}\text { Not good/poor } \\
(29 \%)\end{array}$ & \\
\hline
\end{tabular}


Table 2 shows that the adult-children respondents (86\%) agreed that caring for their elderly parents could bring about family issues. More adult-children (72\%) felt that they were able to offer the care in their parents' home than in their own home (60\%). The adult children agreed (44\%) that, in general, the best living arrangement for their elderly parents after 75 years old was still in the parents' home. Close to one-third (29\%) of the respondents were undecided about this question. The majority of the adult-children respondents (53\%) disagreed that nursing homes were an option for their elderly parents. There were one-fifth (20\%) that favored institutional care and close to one-third (27\%) were undecided. However, $27 \%$ of the respondents felt that institutionalized care could offer better services for their parents. The majority of the respondents (76\%) believed that nursing homes were too expensive. When asked if they harbored any worries about their parents, especially when elderly, the answers were divided. In fact, one-fifth (20\%) answered "not at all", more than one-third (38\%) selected "somewhat", and altogether more respondents (42\%) said that they worry either "quite a bit" or "definitely" (see Table 2).

In Table 3, the statistics displayed are crosstabs meant to analyze the demographic factors of the adult-children respondents as well as how they feel about offering care to their elderly parents. The independent variables are education, income, the number of siblings they have, their parents' health status, and if they would be caregivers in the future. The dependent variables include if the

Table 2. Care values and options by the respondents about caregiving for elderly parents $(\mathrm{n}=100)$.

\begin{tabular}{|c|c|c|c|}
\hline $\begin{array}{l}\text { Caring for elderly } \\
\text { parents can cause family } \\
\text { issues }\end{array}$ & $\begin{array}{l}\text { Strongly agree } \\
(22 \%)\end{array}$ & Agree (64\%) & Disagree $(12 \%) \begin{array}{l}\text { Strongly disagree } \\
(2 \%)\end{array}$ \\
\hline $\begin{array}{l}\text { Be able to care for my } \\
\text { parents in my home }\end{array}$ & $\begin{array}{l}\text { Strongly agree } \\
(16 \%)\end{array}$ & Agree (44\%) & Disagree $(29 \%) \begin{array}{l}\text { Strongly disagree } \\
(11 \%)\end{array}$ \\
\hline $\begin{array}{l}\text { Be able to care for my } \\
\text { parents in their home }\end{array}$ & $\begin{array}{l}\text { Strongly agree } \\
(22 \%)\end{array}$ & Agree (50\%) & Disagree $(21 \%) \begin{array}{l}\text { Strongly disagree } \\
(7 \%)\end{array}$ \\
\hline $\begin{array}{l}\text { The best living } \\
\text { arrangement for parents } \\
75 \text { and older }\end{array}$ & Agree (44\%) & Undecided (29\%) & Disagree (27\%) \\
\hline $\begin{array}{l}\text { Nursing home is an } \\
\text { option for my parents }\end{array}$ & Agree (20\%) & Undecided (27\%) & Disagree (53\%) \\
\hline $\begin{array}{l}\text { Nursing homes are too } \\
\text { expensive for elderly }\end{array}$ & Agree (76\%) & Undecided (17\%) & Disagree (7\%) \\
\hline $\begin{array}{l}\text { My parents can support } \\
\text { nursing home costs }\end{array}$ & Agree (47\%) & Undecided (28\%) & Disagree (25\%) \\
\hline $\begin{array}{l}\text { Nursing homes can offer } \\
\text { better care }\end{array}$ & Agree (27\%) & Undecided (32\%) & Disagree (41\%) \\
\hline $\begin{array}{l}\text { The elderly should seek } \\
\text { out their own } \\
\text { professional care }\end{array}$ & Agree (27\%) & Undecided (35\%) & Disagree (37\%) \\
\hline $\begin{array}{l}\text { Worry about my parents } \\
\text { when elderly }\end{array}$ & Not at all (20\%) & Somewhat (38\%) & $\begin{array}{l}\text { Quite a bit } \\
(22 \%)\end{array}$ \\
\hline
\end{tabular}


Table 3. Crosstab of respondents' demographic variables and care values and options for their elderly parents' living arrangements $(n=100)(\% /$ number of people).

\begin{tabular}{|c|c|c|c|c|c|c|c|c|c|c|c|c|}
\hline & $1^{*}$ & & $2^{*}$ & & $3^{*}$ & & $4^{*}$ & & & $5^{*}$ & & \\
\hline & Agree & Disagree & Agree & Disagree & Agree & Disagree & Agree & Undecided & Disagree & $\begin{array}{c}\text { Parents' } \\
\text { home }\end{array}$ & $\begin{array}{c}\text { Children's } \\
\text { home }\end{array}$ & $\begin{array}{c}\text { Nursing } \\
\text { home }\end{array}$ \\
\hline \multicolumn{13}{|l|}{ Education } \\
\hline $\begin{array}{l}\text { High school or } \\
\text { below }\end{array}$ & $86 \% / 18$ & $14 \% / 3$ & $71 \% / 15$ & $29 \% / 6$ & $67 \% / 14$ & $33 \% / 7$ & $53 \% / 10$ & $26 \% / 5$ & $21 \% / 4$ & $0 \% / 0$ & $50 \% / 6$ & $50 \% / 6$ \\
\hline $\begin{array}{c}\text { Some or college } \\
\text { level }\end{array}$ & $91 \% / 57$ & $9 \% / 6$ & $57 \% / 36$ & $43 \% / 27$ & $71 \% / 45$ & $29 \% / 18$ & $45 \% / 26$ & $33 \% / 19$ & $22 \% / 13$ & $3 \% / 1$ & $44 \% / 17$ & $54 \% / 21$ \\
\hline Graduate school & $69 \% 11$ & $31 \% / 5$ & $56 \% / 9$ & $44 \% / 7$ & $81 \% / 13$ & $19 \% / 3$ & $40 \% / 6$ & $33 \% / 5$ & $27 \% / 4$ & $0 \% / 0$ & $23 \% / 3$ & $77 \% / 10$ \\
\hline \multicolumn{13}{|l|}{ Income } \\
\hline 49,999 or below & $89 \% / 23$ & $11 \% / 3$ & $69 \% / 18$ & $31 \% / 8$ & $58 \% / 15$ & $42 \% / 11$ & $61 \% / 14$ & $26 \% / 6$ & $13 \% / 3$ & $0 \% / 0$ & $44 \% / 7$ & $56 \% / 9$ \\
\hline $50,000-99,999$ & $80 \% / 39$ & $20 \% / 10$ & $63 \% / 31$ & $37 \% / 18$ & $80 \% / 39$ & $20 \% / 10$ & $49 \% / 23$ & $32 \% / 15$ & $19 \% / 9$ & $0 \% / 0$ & $33 \% / 11$ & $57 \% / 22$ \\
\hline $\begin{array}{c}100,000 \text { or } \\
\text { above }\end{array}$ & $95 \% / 19$ & $5 \% / 1$ & $45 \% / 9$ & $55 \% / 11$ & $80 \% / 16$ & $20 \% / 4$ & $16 \% / 3$ & $37 \% / 7$ & $47 \% / 9$ & $9 \% / 1$ & $73 \% / 8$ & $18 \% / 2$ \\
\hline \multicolumn{13}{|l|}{ \# of siblings } \\
\hline 0 - 2 siblings & $89 \% / 49$ & $11 \% / 6$ & $60 \% / 33$ & $40 \% / 22$ & $76 \% / 42$ & $24 \% / 13$ & $48 \% / 25$ & $29 \% / 15$ & $23 \% / 12$ & $3 \% / 1$ & $39 \% / 13$ & $58 \% / 19$ \\
\hline 3 - 4 siblings & $88 \% / 30$ & $12 \% / 4$ & $50 \% / 17$ & $50 \% / 17$ & $71 \% / 24$ & $29 \% / 10$ & $41 \% / 12$ & $41 \% / 12$ & $17 \% / 5$ & $0 \% / 0$ & $44 \% / 11$ & $56 \% / 14$ \\
\hline 5 and more & $60 \% / 6$ & $40 \% / 4$ & $90 \% / 9$ & $10 \% / 1$ & $60 \% / 6$ & $40 \% / 4$ & $50 \% / 5$ & $10 \% / 1$ & $40 \% / 4$ & $0 \% / 0$ & $33 \% / 2$ & $67 \% / 4$ \\
\hline \multicolumn{13}{|l|}{$\begin{array}{l}\text { Will be a future } \\
\text { caregiver }\end{array}$} \\
\hline Yes & $82 \% / 45$ & $18 \% / 10$ & $66 \% / 36$ & $35 \% / 19$ & $80 \% / 44$ & $20 \% / 11$ & $46 \% / 23$ & $36 \% / 18$ & $18 \% / 9$ & $0 \% / 0$ & $34 \% / 12$ & $66 \% / 23$ \\
\hline No & $91 \% / 39$ & $9 \% / 4$ & $54 \% / 23$ & $46 \% / 20$ & $63 \% / 27$ & $37 \% / 16$ & $43 \% / 17$ & $28 \% / 11$ & $30 \% / 12$ & $4 \% / 1$ & $50 \% / 14$ & $46 \% / 13$ \\
\hline
\end{tabular}

$1^{*}$ Caring for elderly parents can bring family care issues. $2^{*}$ Be able to care for my parents in my home $3^{*}$ Be able to care for my parents in their home $4^{*}$ The elderly should seek out their own professional care $5^{*}$ The best living arrangement for parents 75 and older.

respondents feel it would be a problem to take care of the elderly parents, if they are able to offer care in their parents' home or in their own home, the best living arrangements for their parents who are 75 years or older, and if the elderly should seek out their own professional care.

When compared with the levels of education in different groups, those respondents who had obtained graduate degree (69\%), those who received some college or a college degree (91\%), and those who were with high school education or lower $(86 \%)$ were more likely to agree that it is a problem to take care of their elderly parents. Adult-children with high school levels of education were more likely to take care of their parents in their own home (71\%), while respondents with graduate levels of education were more likely to offer the care in their parents' home (81\%). When asked if the elderly should seek out their own professional care, only about a half of the respondents (40\% - 53\%) at varying educational levels agreed, and about one third of the respondents said that they were undecided $(26 \%-33 \%)$. The high school education and lower were equally divided in opinion on the best living arrangement when parents was 75 years old was either staying in their children's home (50\%) or in a nursing home (50\%). There were $77 \%$ of the respondents, who received graduate education, agreed that their parents should be in nursing homes. 
The majority of the adult-children respondents, at all levels of income (80\% 95\%), agreed that taking care of the elderly parents could cause family issues. More than half $(55 \%)$ of the respondents with an income more than $\$ 100,000$ disagreed that they were able to care for their parents in their own home. The majority of the respondents (61\%) with an income of $\$ 49,999$ or below said that the elderly should seek out their own professional care. The respondents with an income more than $\$ 100,000$ said that the best living arrangement for parents who are 75 or older $(73 \%)$ is in their children's home. The more siblings a respondent had, the more likely they disagreed (40\%) that caring for elderly parents can bring family care issues. They also (90\%) agreed that they were able to care for their parents in their own home. If the respondents answered that they would be a caregiver in the future, they (66\%) felt that the best living arrangement for their parents was in a nursing home (see Table 3 ).

In Table 4, the independent variables include the respondents' sex, the current residential status, and their mother and father's health status. The dependent variables are the same ones listed above in Table 3. Both males (62\%) and females (59\%) agreed that they were able to take care of their parents in the respondents' own home. Yet, more respondents stated that they were able to provide care in their parents' home ( $72 \%$ of males and $72 \%$ of females). More females (53\%) than males (38\%) agreed that the elderly should seek out their own

Table 4. Crosstab of respondents' demographic variables and values and options for their elderly parents' living arrangements (n $=100)(\% /$ number of people).

\begin{tabular}{|c|c|c|c|c|c|c|c|c|c|c|c|c|}
\hline & $1^{*}$ & & $2^{*}$ & & $3^{*}$ & & $4^{*}$ & & & $5^{*}$ & & \\
\hline & Agree & Disagree & Agree & Disagree & Agree & Disagree & Agree & Undecided & Disagree & In parents' & In children's & Nursing \\
\hline \multirow{2}{*}{\multicolumn{13}{|c|}{ Sex }} \\
\hline & & & & & & & & & & & & \\
\hline Female & $81 \% / 43$ & $19 \% / 10$ & $59 \% / 31$ & $41 \% / 22$ & $72 \% / 38$ & $28 \% / 15$ & $53 \% / 25$ & $26 \% / 12$ & $21 \% / 10$ & $0 \% / 0$ & $35 \% / 12$ & $65 \% / 22$ \\
\hline Male & $92 \% / 43$ & $9 \% / 4$ & $62 \% / 29$ & $38 \% / 18$ & $72 \% 34$ & $28 \% / 13$ & $38 \% / 17$ & $38 \% / 17$ & $24 \% / 11$ & $3 \% / 1$ & $47 \% / 14$ & $50 \% / 15$ \\
\hline \multicolumn{13}{|c|}{$\begin{array}{l}\text { Current } \\
\text { residential status }\end{array}$} \\
\hline Renting & $93 \% / 13$ & $7 \% / 1$ & $57 \% / 8$ & $43 \% / 6$ & $50 \% / 7$ & $50 \% / 7$ & $9 \% / 1$ & $27 \% / 3$ & $64 \% / 7$ & $0 \% / 0$ & $58 \% / 7$ & $42 \% / 5$ \\
\hline House owners & $87 \% / 71$ & $13 \% / 11$ & $61 \% / 50$ & $39 \% / 32$ & $76 \% / 62$ & $24 \% / 20$ & $51 \% / 39$ & $31 \% / 24$ & $18 \% / 14$ & $2 \% / 1$ & $38 \% / 19$ & $60 \% / / 30$ \\
\hline \multicolumn{13}{|l|}{$\begin{array}{l}\text { My mother's } \\
\text { health status }\end{array}$} \\
\hline Good & $79 \% / 41$ & $21 \% / 11$ & $56 \% / 29$ & $44 \% 23$ & $77 \% / 40$ & $23 \% / 12$ & $61 \% / 30$ & $31 \% / 15$ & $8 \% / 4$ & $61 \% / 30$ & $31 \% / 15$ & $8 \% / 4$ \\
\hline Average & $92 \% / 24$ & $8 \% / 2$ & $58 \% / 15$ & $42 \% / 11$ & $65 \% / 17$ & $35 \% / 9$ & $295 / 7$ & $33 \% / 8$ & $38 \% / 9$ & $29 \% / 7$ & $33 \% / 8$ & $38 \% / 9$ \\
\hline Not healthy & $95 \% / 18$ & $5 \% / 1$ & $74 \% / 14$ & $26 \% / 5$ & $63 \% / 12$ & $37 \% / 7$ & $24 \% / 4$ & $29 \% / 5$ & $47 \% / 8$ & $24 \% / 4$ & $29 \% / 5$ & $47 \% / 8$ \\
\hline \multicolumn{13}{|l|}{$\begin{array}{c}\text { Father's health } \\
\text { status }\end{array}$} \\
\hline Good & $86 \% / 31$ & $14 \% / 5$ & $50 \% / 18$ & $50 \% / 18$ & $69 \% / 25$ & $31 \% / 11$ & $61 \% / 20$ & $27 \% / 9$ & $12 \% / 4$ & $61 \% / 20$ & $27 \% / 9$ & $12 \% / 4$ \\
\hline Average & $77 \% / 10$ & $23 \% / 3$ & $62 \% / 8$ & $39 \% / 5$ & $54 \% / 7$ & $46 \% / 6$ & $64 \% / 7$ & $27 \% / 3$ & $9 \% / 1$ & $64 \% / 7$ & $27 \% / 3$ & $9 \% / 1$ \\
\hline Not healthy & $90 \% / 18$ & $10 \% / 2$ & $55 \% / 11$ & $45 \% / 9$ & $70 \% / 14$ & $30 \% / 6$ & $21 \% / 4$ & $21 \% / 4$ & $58 \% / 11$ & $21 \% / 4$ & $21 \% / 4$ & $58 \% / 11$ \\
\hline
\end{tabular}

$1^{\star}$ Caring for elderly parents can bring family care issues. $2^{\star}$ Be able to care for my parents in my home. $3^{\star}$ Be able to care for my parents in their home. $4^{\star}$ The elderly should seek out their own professional care. $5^{*}$ The best living arrangement for parents 75 and older. 
(65\%) felt that their elderly parents should use nursing homes when they are professional care. This trend continued as fewer males (50\%) than females aged 75 years or older. Those respondents whose mother's (95\%) and/or father's (90\%) health status was poor or unhealthy were likely to feel that caring for elderly parents could bring family issues. Regardless if parents' health status is good or unhealthy, the majority of the respondents felt that caring for their elderly parents could bring family care issues. The respondents' parents (mother $47 \%$, father, $58 \%$ ) with poor health agreed that their parents should be in nursing homes. The majority of them were able to take care of their parents in their own home or their parents' home. It did not make a difference between the respondents' residential pattern who was renting (57\%) and homeowners (61\%). However, adult-children who were homeowners (60\%) preferred that their parents live in nursing homes as well as felt that the elderly should seek out their own professional care (51\%).

Table 5 analyzes the demographic factors of the adult-children respondents as well as how they feel about offering care to their elderly parents. The independent variables are still the same as the ones in Table 3. The dependent variables include nursing homes are too expensive for elderly, nursing homes are an option for my parents, my parents can support nursing home finances, and I worry

Table 5. Crosstab of respondents' demographic variables and values and options for their elderly parents living arrangements $(\mathrm{n}=$ 100) (\%/number of people).

\begin{tabular}{|c|c|c|c|c|c|c|c|c|c|c|c|}
\hline \multicolumn{3}{|c|}{$6^{*}$} & \multicolumn{3}{|c|}{$7^{*}$} & \multicolumn{3}{|c|}{$8^{*}$} & \multicolumn{3}{|c|}{$9^{*}$} \\
\hline & Agree & Undecided & Disagree & Agree & Undecided & Disagree & Agree & Undecided & Disagree & Agree & Disagree \\
\hline \multicolumn{12}{|l|}{ Education } \\
\hline $\begin{array}{l}\text { High school or } \\
\text { below }\end{array}$ & $0 \% / 0$ & $50 \% / 6$ & $50 \% / 6$ & $14 \% / 3$ & $76 \% / 16$ & $10 \% / 2$ & $12 \% / 2$ & $41 \% / 7$ & $47 \% / 8$ & $57 \% / 12$ & $43 \% / 9$ \\
\hline $\begin{array}{c}\text { Some or college } \\
\text { level }\end{array}$ & $3 \% / 1$ & $44 \% / 17$ & $54 \% / 21$ & $22 \% / 14$ & $65 \% / 41$ & $13 \% / 8$ & $17 \% / 7$ & $52 \% / 22$ & $31 \% / 13$ & $62 \% / 39$ & $38 \% / 24$ \\
\hline Graduate school & $0 \% / 0$ & $23 \% / 3$ & $77 \% / 10$ & $19 \% / 3$ & $50 \% / 8$ & $31 \% / 5$ & $15 \% / 2$ & $54 \% / 7$ & $31 \% / 4$ & $44 \% / 7$ & $56 \% / 9$ \\
\hline \multicolumn{12}{|l|}{ Income } \\
\hline 49.999 or below & $0 \% / 0$ & $44 \% / 7$ & $56 \% / 9$ & $15 \% / 4$ & $69 \% / 18$ & $15 \% / 4$ & $16 \% / 3$ & $52 \% / 10$ & $32 \% / 6$ & $62 \% / 16$ & $38 \% / 10$ \\
\hline $50,000-99,999$ & $0 \% / 0$ & $33 \% / 11$ & $67 \% / 22$ & $22 \% / 11$ & $63 \% / 31$ & $14 \% / 7$ & $14 \% / 5$ & $57 \% / 20$ & $29 \% / 10$ & $59 \% / 29$ & $41 \% / 20$ \\
\hline 100,000 or above & $9 \% / 1$ & $73 \% / 8$ & $18 \% / 2$ & $25 \% / 5$ & $60 \% / 12$ & $15 \% / 3$ & $14 \% / 2$ & $29 \% / 4$ & $57 \% / 8$ & $50 \% / 10$ & $42 / 40$ \\
\hline \multicolumn{12}{|l|}{ \# of siblings } \\
\hline 0 - 2 siblings & $3 \% / 1$ & $39 \% / 13$ & $58 \% / 19$ & $16 \% / 9$ & $71 \% / 39$ & $13 \% / 7$ & $14 \% / 5$ & $54 \% / 20$ & $32 \% / 12$ & $56 \% / 31$ & $44 \% / 24$ \\
\hline 3 - 4 siblings & $0 \% / 0$ & $44 \% / 11$ & $56 \% / 14$ & $24 \% / 8$ & $59 \% / 20$ & $18 \% / 6$ & $19 \% / 5$ & $42 \% / 11$ & $39 \% / 10$ & $59 \% / 20$ & $41 \% / 14$ \\
\hline 5 and more & $0 \% / 0$ & $33 \% / 2$ & $67 \% / 4$ & $30 \% / 3$ & $50 \% / 5$ & $205 / 2$ & $11 \% / 1$ & $56 \% / 5$ & $33 \% / 3$ & $60 \% / 6$ & $40 \% / 4$ \\
\hline \multicolumn{12}{|l|}{$\begin{array}{l}\text { Will be a } \\
\text { future caregiver }\end{array}$} \\
\hline Yes & $0 \% / 0$ & $34 \% / 12$ & $66 \% / 23$ & $15 \% / 8$ & $67 \% / 37$ & $18 \% / 10$ & $16 \% / 7$ & $47 \% / 20$ & $37 \% / 16$ & $44 \% / 24$ & $56 \% / 31$ \\
\hline No & $4 \% / 1$ & $50 \% / 14$ & $46 \% / 13$ & $25 \% / 11$ & $63 \% / 27$ & $12 \% / 5$ & $15 \% / 4$ & $56 \% / 15$ & $30 \% / 8$ & $79 \% / 34$ & $21 \% / 9$ \\
\hline
\end{tabular}

$6^{\star}$ Nursing homes are too expensive for elderly. $7^{\star}$ Nursing homes are an option for parents. $8^{\star}$ My parents can support nursing home. $9^{\star}$ Worry about my parents when elderly. 
about my parents when they become elderly.

The respondents with college levels of education or below showed that they were either undecided $(44 \%-50 \%)$ or disagreed $(50 \%-54 \%)$ when they were asked if they felt nursing homes were too expensive for the elderly. The respondents $(77 \%)$ with graduate levels of education disagreed that nursing homes were too expensive for their parents. More respondents with college levels of education or below agreed $(57 \%-62 \%)$ that they worried about their parents when elderly, but the respondents with graduate levels of education slightly descended from that opinion (44\%). When asking the respondents with different levels of income if nursing homes were expensive or not, those with income levels of $\$ 100,000$ as their yearly income said that they were undecided $(73 \%)$, they also disagreed that their parents could afford nursing homes (57\%). The respondents who had an income lower than $\$ 100,000$ disagreed that the nursing homes were too expensive for their elderly parents (56\% - 67\%). The respondents, who had five or more siblings (67\%), had a relatively higher percentage believing that nursing homes were expensive, when compared with respondents with fewer siblings ( $58 \%$ of $0-2$ siblings and $56 \%$ of $3-4$ siblings). Those with 0 - 2 siblings (71\%) were more at the category of undecided than those respondents who had more siblings (59\% of 3 - 4 siblings and $50 \%$ of 5 and more siblings) believing that nursing homes were an option for their parents. The respondents who believed that they would be the designated caregivers for their elderly parents (44\%) agreed that they worry about their parents. Worrying about their parents was even higher among the respondents that did not foresee themselves as a caregiver for their parents (79\%).

Table 6 shows that females (65\%) disagreed that nursing homes were expensive and males were divided between the categories of undecided (47\%) and disagreed (50\%). Both males (52\%) and females (49\%) had slightly higher percentages of undecided than disagreement (males $41 \%$ and females $30 \%$ in the category of disagreement) about whether their parents can support nursing homes financially. More respondents who were homeowners (60\%) than renters (42\%) disagreed that nursing homes were too expensive, but renters (50\%) agreed that nursing homes were an option for their elderly parents (house owners 15\%). Both renters (57\%) and homeowners (57\%) in the survey agreed that they worried about their elderly parents. The respondents whose parents' health status was good disagreed nursing homes were too expensive (mother $74 \%$ and father 75\%) and held undecided attitudes about if nursing homes were an option for their parents (mother $71 \%$ and father 67\%). On the contrary, if their parents' health status was unhealthy or poor, relatively lower percentages of the respondents disagreed nursing homes were too expensive (mother 39\% and father 36\%) and they also disagreed that their parents (mother 53\% and father 53\%) could support nursing homes financially.

\section{Discussion and Conclusion}

This study revealed a variety of results about the adult-children respondents and 
Table 6. Crosstab of respondents' demographic variables and values and options for their elderly parents living arrangements $(\mathrm{n}=$ 100) (\%/number of people).

\begin{tabular}{|c|c|c|c|c|c|c|c|c|c|c|c|}
\hline \multicolumn{3}{|c|}{$6^{*}$} & \multicolumn{3}{|c|}{$7^{*}$} & \multicolumn{3}{|c|}{$8^{*}$} & \multicolumn{3}{|c|}{$9^{*}$} \\
\hline & Agree & Undecided & Disagree & Agree & Undecided & Disagree & Agree & Undecided & Disagree & Agree & Disagree \\
\hline \multicolumn{12}{|l|}{ Sex } \\
\hline Female & $0 \% / 0$ & $35 \% / 12$ & $65 \% / 22$ & $17 \% / 9$ & $64 \% / 34$ & $19 \% / 10$ & $21 \% / 9$ & $49 \% / 21$ & $30 \% / 13$ & $55 \% 29$ & $45 \% / 24$ \\
\hline Male & $3 \% / 1$ & $47 \% / 14$ & $50 \% / 15$ & $23 \% / 11$ & $66 \% / 31$ & $11 \% / 5$ & $7 \% / 2$ & $52 \% / 15$ & $41 \% / 12$ & $62 \% / 29$ & $38 \% / 18$ \\
\hline \multicolumn{12}{|l|}{$\begin{array}{l}\text { Current } \\
\text { residential status }\end{array}$} \\
\hline Renting & $0 \% / 0$ & $58 \% / 7$ & $42 \% / 5$ & $50 \% / 7$ & $29 \% / 4$ & $21 \% / 3$ & $17 \% / 2$ & $42 \% / 5$ & $42 \% / 5$ & $57 \% / 8$ & $43 \% / 6$ \\
\hline House owners & $2 \% / 1$ & $38 \% / 19$ & $60 \% / 30$ & $15 \% / 13$ & $73 \% / 60$ & $11 \% / 9$ & $14 \% / 8$ & $52 \% / 30$ & $35 \% / 20$ & $57 \% / 47$ & $43 \% / 35$ \\
\hline \multicolumn{12}{|l|}{$\begin{array}{l}\text { My mother's } \\
\text { health status }\end{array}$} \\
\hline Good & $0 \% / 0$ & $26 \% / 8$ & $74 \% / 23$ & $15 \% / 8$ & $71 \% / 37$ & $14 \% / 7$ & $18 \% / 6$ & $56 \% / 19$ & $27 \% / 9$ & $62 \% / 32$ & $38 \% / 20$ \\
\hline Average & $0 \% / 0$ & $47 \% / 8$ & $53 \% / 9$ & $31 \% / 8$ & $58 \% / 15$ & $12 \% / 3$ & $10 \% / 2$ & $55 \% / 11$ & $35 \% / 7$ & $58 \% / 15$ & $42 \% / 11$ \\
\hline Not healthy & $8 \% / 1$ & $54 \% / 7$ & $39 \% / 5$ & $4 \% / 21$ & $63 \% / 12$ & $16 \% / 3$ & $20 \% / 3$ & $27 \% / 4$ & $53 \% / 8$ & $47 \% / 9$ & $53 \% / 10$ \\
\hline \multicolumn{12}{|l|}{$\begin{array}{l}\text { My father's } \\
\text { health status }\end{array}$} \\
\hline Good & $0 \% / 0$ & $25 \% / 5$ & $75 \% / 15$ & $19 \% / 7$ & $67 \% / 24$ & $14 \% / 5$ & $24 \% / 6$ & $64 \% / 16$ & $12 \% / 3$ & $67 \% / 24$ & $33 \% / 12$ \\
\hline Average & $0 \% / 0$ & $44 \% / 4$ & $56 \% / 5$ & $15 \% / 2$ & $62 \% / 8$ & $23 \% / 3$ & $11 \% / 1$ & $67 \% / 6$ & $225 / 2$ & $62 \% / 8$ & $39 \% / 5$ \\
\hline Not healthy & $7 \% / 1$ & $57 \% / 8$ & $36 \% / 5$ & $45 \% / 9$ & $40 \% / 8$ & $15 \% / 3$ & $18 \% / 3$ & $29 \% / 5$ & $53 \% / 9$ & $50 \% / 10$ & $50 \% / 10$ \\
\hline
\end{tabular}

$6^{*}$ Nursing homes are too expensive for elderly. $7^{*}$ Nursing homes are an option for parents. $8^{*}$ My parents can support nursing homes financially. $9^{*}$ Worry about my parents when elderly.

the care of their elderly parents. Some influential factors are worth noting. For example, compared to other studies on a similar topic, this particular research found that the respondents' care values and options on the caregiving and living arrangements for their parents were highly dependent on different respondents' background variables as well as the situations that they had to face. These influential factors could be their parents' health conditions, the number of siblings they had, and/or if they would be a caregiver in the future. It is often assumed that nursing homes are too expensive; however, many respondents in the survey displayed overall disagreement or were undecided about this notion. The data also indicated that the respondents with varying background situations had diverse answers on the care for their parents. For instance, more respondents with a graduate level of education agreed that they were able to care for their parents in the parents' home, but fewer respondents at college or lower levels of education agreed. A respondent who had five or more siblings was more likely to agree that they would be able to care for their parents in the respondents' home than those who had fewer siblings.

Other than the differences based on the respondents' demographic background variables, there were also some similarities. The majority of the respondents agreed that taking care of their elderly parents could cause family issues, but those respondents who had more siblings had relatively lower percentage to 
agree that the caregiving would result in family issues. When comparing the answers to the survey questions about whether they were more likely to care for their parents in the parents' home or in their own home, more respondents agreed to offer the care in their parents' home. The answers indicated the adultchildren's concerns about causing their family any problems and about the independence of their parents as well as the respondents' own family life. This is because the majority of the respondents were married in this survey. They believed that the elderly parents should seek out their own professional care. They considered that nursing homes were an option and they also felt institutionalized care facilities were the best living arrangement for their parents when they are 75 years or older. This was true even though most of the respondents expressed that they worried about their parents. The results of the survey also revealed in our current society there were more people who accept nursing homes as a justifiable option for elderly care. Yet, there is still apprehension about the high costs associated with such options. The survey results also indicated that the leading pattern of caregiving still highly depended on family care. However, the caregiving pattern has been leaning increasingly toward to the acceptance of institutionalized care services. This survey showed that at least the adult-children respondents in this survey were more likely to agree the nursing homes were an option for their parents.

As previously discussed throughout this article, the adult-children respondents' background information has caused different responses on care values and options towards caring for their parents. With the aging of baby-boomer parents, there has become a gradual change in adult-children's opinions on living arrangements, and this change from informal home care towards institutionalized services has occurred for a variety of reasons. This is because babyboomer parents have fewer children when establishing their own families. This is demonstrated in the survey, which showed that 56 out of 100 respondents who had 0 to 2 siblings. In addition to smaller families, social changes like technological advancement in the medical field, people now live much longer than before. With fewer children and longer life expectancy, the elderly are facing a shortage in informal care from their adult-children.

In the past, females were expected to offer care to their elderly parents or in-laws, because of their role as nurturers and homemakers. However, in today's society, both men and women work in order to support their own families. This has resulted in the adult-children struggling to balance time between providing adequate assistance to their parents and duties associated with their own families and work. Therefore, new solutions are so important to address the caring needs for the parents. Now, the majority of the respondents tended to indicate that they were undecided for many of the questions, which showed that they were not as available to provide the same amount and quality of help as other adult-children did in the past. Yet, they could not make up their minds about using institutionalized care facilities. Nursing homes in this survey were more likely to become a viable option for parents who had poor health, for respon- 
dents who believed that they would become a caregiver in the future, for female respondents, and/or for those with a graduate level of education. All of these demographic factors suggested that adult-children were not ready to commit to the time required for providing excessive care needs.

A majority of the respondents stated that they worried about their parents and they were undecided if their parents were able to support their own nursing home expenses. This situation has brought some social concerns. First, with the cost of our current institutionalized care facilities, many elderly did not have enough financial savings to support themselves to use professional care services. Second, while there was a concern about the quality of institutionalized care services causing people to feel reluctant about having their elderly parents there. However, they now were more likely to consider it as an option, especially if they could no longer assist their parents at home. The last concern was that care-related responsibilities for the elderly parents could cause their family issues, such as conflict between siblings, disagreement between couples, differing lifestyles, and finding the time and resources to fulfill work and family needs.

With more baby-boomers reaching their senior age, informal care is still a popular option; however, there are many issues to be considered with this particular type of care. This pattern needs to be studied in order to create possible solutions for addressing the rapid growth of the elderly, who will start to require this type of assistance. This survey found that when discussing the informal care by adult-children, a majority of the respondents agreed that they worried about their parents and were undecided about using nursing homes. The majority of the respondents clearly stated that they were able to offer the care in their parents' home. Other respondents also expressed that they were able to take care of their parents in their own home. In conclusion, with the longer life expectancy as well as more elderly people in the American society, both informal and formal systems for providing care are important in the future. The adult-children respondents' attitudes toward caring for their parents indicated that they were willing to offer the care for their parents, but they were also willing or more susceptible to the notion of using institutionalized care services.

\section{References}

[1] Willetts, D. (2011) The Pinch: How the Baby Boomers Took Their Children's Future and Why They Should Give It Back. Atlantic Books.

[2] Rogerson, P.A. and Kim, D. (2005) Population Distribution and Redistribution of the Baby-Boom Cohort in the United States: Recent Trends and Implications. Proceedings of the National Academy of Sciences, 102, 15319-15324.

https://www.ncbi.nlm.nih.gov/pmc/articles/PMC1266126/ https://doi.org/10.1073/pnas.0507318102

[3] Hearl, M. (2011) How Many Seniors Really End Up in Nursing Homes? Aging Options.

http://www.agingoptions.com/2011/10/how-many-seniors-really-end-up-in-nursin g-homes/

[4] East, P.L. (2010) Children's Provision of Family Care Giving: Benefit or Burden? 
Child Development Perspectives, 4, 55-61.

https://doi.org/10.1111/j.1750-8606.2009.00118.x

[5] Scommegna, P. (2016) Today's Research on Aging: Family Care Giving. Population Reference Bureau.

http://www.prb.org/Publications/Reports/2016/todays-research-aging-caregiving.as px

[6] Family Caregiver Alliance (2015) Selected Long-Term Care Statistics. https://www.caregiver.org/selected-long-term-care-statistics

[7] Spillman, B.C. and Lubitz, J. (2002) New Estimates of Lifetime Nursing Home Use: Have Patterns of Use Changed? Medical Care, 40, 965-975. https://doi.org/10.1097/00005650-200210000-00013

[8] Raina, P., O’Donnell, M., Schwellnus, H., Rosenbaum, P., King, G., Brehaut, J. and Walter, S.D. (2004) Care Giving Process and Caregiver Burden: Conceptual Models to Guide Research and Practice. BMC Pediatrics, 4, 1. https://doi.org/10.1186/1471-2431-4-1

[9] Neal, M.B. and Hammer, L.B. (2007) Working Couples Caring for Children and Aging Parents: Effects on Work and Well-Being. Lawrence Erlbaum Associates. http://www.web.pdx.edu/ rosine/sandwich/NealHammerExecSum.pdf

[10] Williams, C. (2004) The Sandwich Generation. Perspectives on Labour and Income, 16,7 .

[11] Stuifbergen, M.C. and Van Delden, J.M. (2011) Filial Obligations to Elderly Parents: A Duty to Care? Medicine, Health Care, and Philosophy, 14, 63-71. https://www.ncbi.nlm.nih.gov/pmc/articles/PMC3015170/ https://doi.org/10.1007/s11019-010-9290-Z

[12] Min, J.W. and Barrio, C. (2009) Cultural Values and Caregiver Preference for Mexican-American and Non-Latino White Elders. Journal of Cross-Cultural Gerontology, 24, 225-239. https://www.ncbi.nlm.nih.gov/pmc/articles/PMC2943061/ https://doi.org/10.1007/s10823-008-9088-0

[13] Parker, K. and Patten, E. (2013) The Sandwich Generation Rising Financial Burdens for Middle-Aged Americans. http://www.pewsocialtrends.org/2013/01/30/the-sandwich-generation/

[14] Ramnarace, C. (2010) I Love You, Mom. But You're Driving Me Crazy. AARP Bulletin.

http://www.aarp.org/relationships/caregiving/info-102010/i_love_you_mom_but_y oure_driving_me_crazy.html

[15] Bui, H. (2014) Elderly Care Giving: Daughters, Not Sons, Step Up. USA Today. http://www.usatoday.com/story/news/nation/2014/08/19/elderly-care-caregiving-w omen/14254647/

[16] Pinquart, M. and Sörensen, S. (2003) Differences between Caregivers and Non Caregivers in Psychological Health and Physical Health: A Meta-Analysis. Psychology and Aging, 18, 250. https://doi.org/10.1037/0882-7974.18.2.250

[17] Pinquart, M. and Sörensen, S. (2011) Spouses, Adult Children, and Children-in-Law as Caregivers of Older Adults: A Meta-Analytic Comparison. Psychology and Aging, 26, 1-14. http://www.ncbi.nlm.nih.gov/pmc/articles/PMC4449135/ https://doi.org/10.1037/a0021863

[18] Cherlin, A.J. (2010) Demographic Trends in the United States: A Reveal of Research in the 2000s. Journal of Marriage and Family, 72, 403-419. https://doi.org/10.1111/j.1741-3737.2010.00710.x

[19] Bonsang, E. (2007) How Do Middle-Aged Children Allocate Time and Money 
Transfers to Their Older Parents in Europe? Empirica, 34, 171-188.

https://doi.org/10.1007/s10663-007-9034-3

[20] Tolkacheva, N., Van Groenou, M.B. and Van Tilburg, T. (2014) Sibling Similarities and Sharing the Care of Older Parents. Journal of Family Issues, 35, 312-330. https://doi.org/10.1177/0192513X12470619

Submit or recommend next manuscript to SCIRP and we will provide best service for you:

Accepting pre-submission inquiries through Email, Facebook, LinkedIn, Twitter, etc. A wide selection of journals (inclusive of 9 subjects, more than 200 journals)

Providing 24-hour high-quality service

User-friendly online submission system

Fair and swift peer-review system

Efficient typesetting and proofreading procedure

Display of the result of downloads and visits, as well as the number of cited articles Maximum dissemination of your research work

Submit your manuscript at: http://papersubmission.scirp.org/

Or contact jss@scirp.org 